\title{
Microwave Assisted Expeditious and Green Cu(II)-Clay Catalyzed Domino One-Pot Three Component Synthesis of $2 \mathrm{H}$-indazoles
}

\author{
Bashir Ahmad Dara*, Syed Wasim Safvi ${ }^{b}$, Masood Ahmad Rizvi ${ }^{b}$ \\ ${ }^{a}$ Department of Chemistry, Govt., Degree College Boys, Sopore Jammu \& Kashmir, 193201 India \\ ${ }^{b}$ Department of Chemistry, University of Kashmir, Hazratbal, Srinagar, J\&K, India
}

Received: 24 ${ }^{\text {th }}$ February 2017; Revised: $8^{\text {th }}$ August 2017; Accepted: $23^{\text {rd }}$ August 2017

Available online: $22^{\text {nd }}$ January 2018; Published regularly: $2^{\text {nd }}$ April 2018

\begin{abstract}
A simple and efficient synthesis of $2 \mathrm{H}$-indazoles is achieved from 2-primary amines, bromobenzaldehydes and sodium azide through domino condensation, $\mathrm{C}-\mathrm{N}$ and $\mathrm{N}-\mathrm{N}$ bond formations, catalyzed by a heterogeneous $\mathrm{Cu}(\mathrm{II})$-Clay catalyst. The recyclable heterogeneous $\mathrm{Cu}(\mathrm{II})$-Clay catalyst exhibited a remarkable activity for the title reaction without any additives. An assortment of structurally diverse $2 \mathrm{H}$-indazoles were prepared in good to excellent yields from easily available starting materials by using this protocol. The $\mathrm{Cu}(\mathrm{II})$-Clay catalyst was characterized by using X-Ray Diffraction (XRD), Scanning Electron Microscopy (SEM), and Brunauer-Emmett-Teller (BET) techniques. Copyright (C) 2018 BCREC Group. All rights reserved
\end{abstract}

Keywords: 2H-indazoles; Copper catalyst; Multi-component reaction; Green synthesis; Neat protocol

How to Cite: Dar, B.A., Safvi, S.W., Rizvi, M.A. (2018). Microwave Assisted Expeditious and Green $\mathrm{Cu}(\mathrm{II})$-Clay Catalyzed Domino One-Pot Three Component Synthesis of $2 \mathrm{H}$-indazoles. Bulletin of Chemical Reaction Engineering \& Catalysis, 13 (1): 82-88 (doi:10.9767/bcrec.13.1.963.82-88)

Permalink/DOI: https://doi.org/10.9767/bcrec.13.1.963.82-88

\section{Introduction}

The importance of indazole derivatives as pharmacophores in drug discovery is well exemplified by its broad application in antitumor, [1] anti-HIV [2], antidepressant [3], antimicrobial [4], anti-angiogenic [5], and anti-pyretic [6]. In addition, indazoles are widely used as precursors in the synthesis of many natural products like nigellcine and nigellidine [7]. Owing to their importance as pharmaceuticals, agrochemicals, and novel materials a plethora of methods have been developed for their synthesis, such as: Cadogan indazole synthesis [8], cyclization reactions to selectively generate $2 \mathrm{H}$ -

* Corresponding Author.

E-mail: bashir_15_dar@yahoo.com (Dar, B.A.) indazoles [9], reductive cyclization of orthoimino-nitrobenzenes mediated by triethyl phosphite, transition metal catalyzed reductive cyclizations of iminonitroaromatic [10], sydnone/benzyne cycloaddition [11], zincate addition to diazonium salts [12], intramolecular aminations [13], and condensation of benzaldehydes with hydrazine [14].

Many of these methods suffer with drawbacks in terms of substrate scope, reaction conditions, reaction time, unsatisfactory yields, elevated temperatures, and/or protected syntheses of substrates. Consequently, there is a need to develop environment friendly, operationally simple and mild methods to obtain this privileged pharmacophore from a broad class of readily available synthetic reagents. 
Clays are considered to be potentially the most cost-effective and environmentally benign catalysts for organic reactions [15]. The metal doped clays can be the hybrid materials with combined catalytic rewards of metal salts and clay catalysts. Thus, in continuation of our interests [16-21], we herein report synthesis of $2 \mathrm{H}$-indazoles from readily available 2 -primary amines, bromobenzaldehydes and sodium azide using a heterogeneous $\mathrm{Cu}(\mathrm{II}) /$ Montmorilloniteclay catalyst. The advantages of the system include, short reaction times, catalyst recyclability, neat conditions, remarkable activity without any additives and amenable for synthesis of diverse $2 \mathrm{H}$-indazoles.

\section{Materials and Methods}

\subsection{Preparation of the catalyst}

$\mathrm{Cu}(\mathrm{II})$-clay catalyst was prepared by introducing of calculated amount of aqueous Copper oligomer (prepared from copper(II) chloride precursor) to form a 10 wt.\% copper loading (pre-optimized loading) on to Montmorillonite KSF clay (purchased from Sigma-Aldrich) and the system was stirred for $15 \mathrm{~h}$ followed by filtration and then washed with distilled water several times to remove chlorides. The cake so formed was dried at room temperature, kept overnight in air oven at $110{ }^{\circ} \mathrm{C}$ and then powdered and calcined in air at $425{ }^{\circ} \mathrm{C}$ for $3 \mathrm{~h}$. The calcined product is referred to as $\mathrm{Cu}(\mathrm{II})$ doped clay catalyst (CDC 2) and the catalyst so formed was used in the experiments without further activation.

\subsection{Procedure for the preparation of $2 \mathrm{H}$ - indazoles}

Reaction mixture (in a typical reaction 1.0 mmol 2-bromobenzaldehyde, $1.2 \mathrm{mmol}$ aniline, $1.8 \mathrm{mmol}$ sodium azide, and $5 \mathrm{mg} \mathrm{Cu}-\mathrm{Clay}$

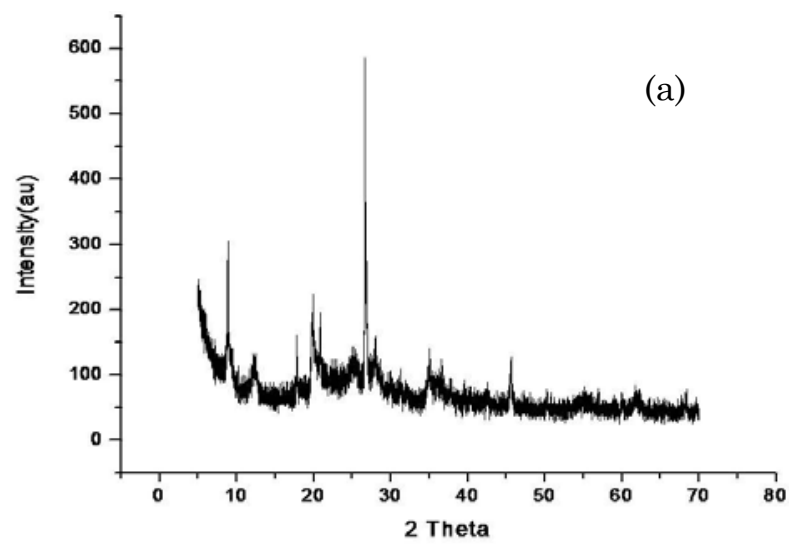

catalyst were taken into a Scientific Microwave Synthesizer CATA - R I operating at 300 watts, and irradiated for 8 minutes. On completion of the reaction, followed by thin layer chromatography (TLC) examination, the mixture was cooled to room temperature, dissolved in ethyl acetate and filtered to separate the catalyst. The filtrate was concentrated under high vacuum. The crude products were purified by crystallization and the pure products were characterized by nuclear magnetic resonance spectroscopy (NMR) and mass analysis and the characterization data of the synthesized compounds was compared with the literature reports.

\subsection{Catalyst characterization}

The XRD analysis of $\mathrm{Cu}(\mathrm{II})$-clay catalyst was done by recording X-ray powder diffraction patterns on a Rigaku Miniflex diffractometer, using Ni-filtered $\mathrm{Cu}-\mathrm{Ka}(0.15418 \mathrm{~nm})$ radiation source (Figure 1). The sample was scanned over the range 5.00-70.99 on $2 \mathrm{u}$ scale with steps 0.0118 and step time $13.6 \mathrm{~s}$. To study the morphology, a SEM of the catalyst was carried out using JEOL JEM100CXII ELECTRON MICROSCOPE with ASID Accelerating Voltage $40.0 \mathrm{KV}$. The BET surface area of the catalyst was determined using the instrument SMART SORB 92/93 under the liquid nitrogen.

\section{Results and Discussion}

In this protocol, we used $\mathrm{Cu}(\mathrm{II})$-clay catalyst with 10 wt.\% copper loading, which was preoptimized. The best yield was found by $10 \mathrm{wt} . \%$ copper loading may be due to its optimum nano size of the catalyst and hence increased number of active catalytic sites are produced. Higher copper loading may direct increased in the particle size formation of $\mathrm{CuO}$ and hence lesser surface area and lesser number of active

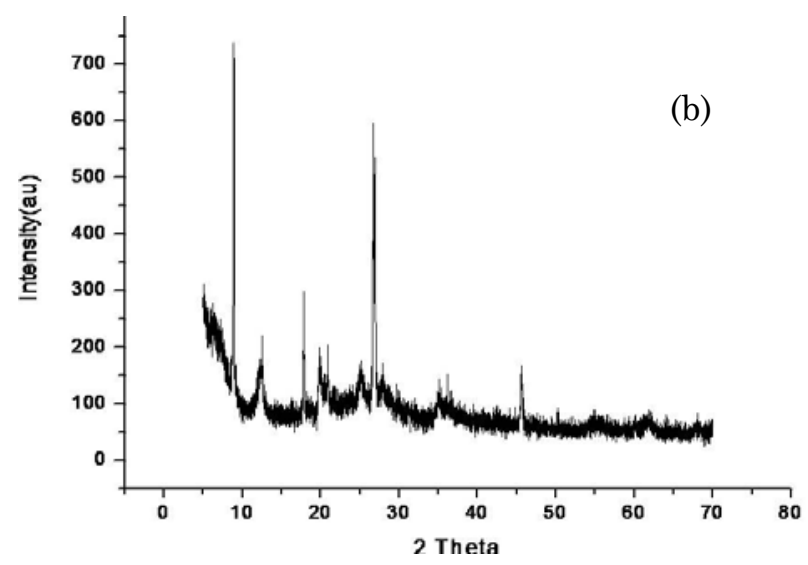

Figure 1. XRD peaks of fresh $\mathrm{Cu}(\mathrm{II})$-clay 
sites. Lower copper loading leads to lower active catalyst quantity.

This catalyst was characterized by using different instrumental techniques to support our results. The XRD patterns of the fresh $\mathrm{Cu}(\mathrm{II})$ clay catalyst are shown in Figure 1a. The $2 \theta$ at $8.4^{\circ}$ is commonly assigned to the characteristic peak of basal spacing $(d 001)(2: 1$ TOT) of montomorillonite-KSF; the basal reflection represents the distance between two clay layers, including the thickness of one of the layers [22]. The presence of very low intensity diffraction peaks at $2 \theta$ of $36.1,37.7,38.9,48.8,53.60$, and 58.7 which attributing to (110), (002), (111), (202) of $\mathrm{CuO}$ indicates that there are no sharp crystalline phases thus $\mathrm{CuO}$ being supported on MKSF in the form highly dispersed fine particles [23]. Peaks at $2 \theta$ of $20.9,26.9,36.5,39.2$, 48.6, 50.0, and 59.6 are due to reflection of the quartz $\left(\mathrm{SiO}_{2}\right)$ impurities [24]. Other peaks for montomorillonite appear at $2 \theta$ of 20.0, 24.3, 29.8 and 35.5. A sharp peak observed at $2 \theta$ of 17.8 along with some small peaks at $30.1,36.0$ and 47.2 correspond to the presence of Melanothallite $\left[\mathrm{Cu}_{2} \mathrm{OCl}_{2}\right]$. Presence of Kaolinite is implied to a sharp peak at 12.0 which corresponds to (001) and other peaks for this material appear at $24.1,32.3,38.0$, and 42.7 . There are two additional humps one at 55.0 and other at 61.9 which are due to montomorillonite and $\mathrm{CuO}$ in bulk, respectively [25]. Comparison of XRD patterns of the fresh catalyst with that of used catalyst (Figure $1 b$ ), clearly shows that there is almost no change in catalyst texture after use, which guarantees robustness and recyclability of the catalyst.

The SEM images of the Montmorilonite$\mathrm{KSF}$ and $\mathrm{Cu}$ (II)-clay with 20000 magnifications are displayed in Figure 2. The montmorilonite$\mathrm{KSF}$ without $\mathrm{CuO}$ (Figure 2a) possess smooth surface without any scrap but turns crumby af-

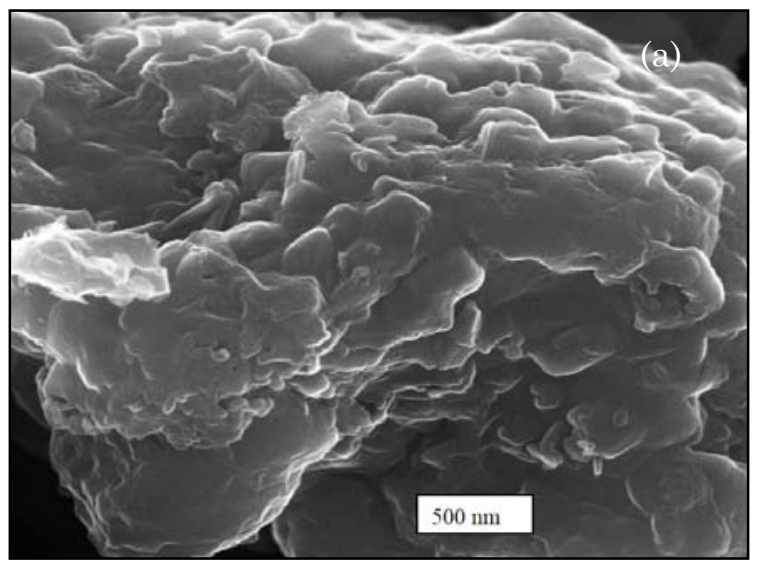

ter loading of $\mathrm{CuO}$. Figure $2 \mathrm{~b}$ clearly shows that $\mathrm{CuO}$ particles are highly dispersed over the support surface in the form of nano aggregates which in agreement with the XRD pattern. The nanosized $\mathrm{CuO}$ distributed in mosaic form on the surface of the clay leads to coarse surface (thus elevated surface area). From the SEM (EDAX) elemental analysis it was found that the catalyst prepared contains $9.21 \%$ of copper loaded. The surface area of the catalyst is $96.4551 \mathrm{~m}^{2} / \mathrm{g}$, where as that of montmorillonite-KSF clay support only is $37.35 \mathrm{~m}^{2} / \mathrm{g}$. The increase in specific surface area of the catalyst may be due to mesopores formed by delamination of support during the process of catalyst preparation.

We began our efforts with the reaction of 2-bromobenzaldehyde, aniline, and sodium azide (1 mmol each) in toulene at room temperature which only to find no product formation (Table 1 entry 1). This led us to increase the reaction temperature to $120{ }^{\circ} \mathrm{C}$, which to our delight gave corresponding indazole in about $12 \%$ yields. While operating at this temperature, we changed ratio of the reactants from $1: 1: 1$ to $1: 1.2: 1$, respectively, the product yield did no change by more than $2 \%$. By using ratio of $1: 1.2: 1.2$ of the reactants, the product yield increased to approximately $21 \%$ and at ratio of $1: 1.2: 1.5$, it raised to $30 \%$. When the ratio was changed to $1: 1.2: 1.8$, product yield increased slightly, i.e. to $34 \%$ (Table 1 entry 2 based Scheme 1). These results warranted optimization of the reaction conditions.

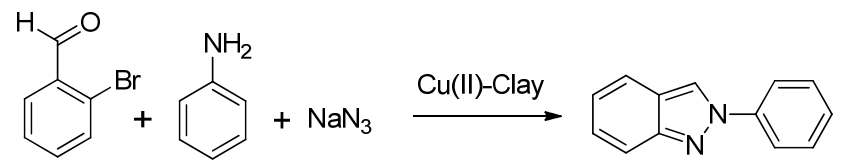

Scheme 1. Synthesis of $2 \mathrm{H}$-indazoles using $\mathrm{Cu}$ Clay catalyst

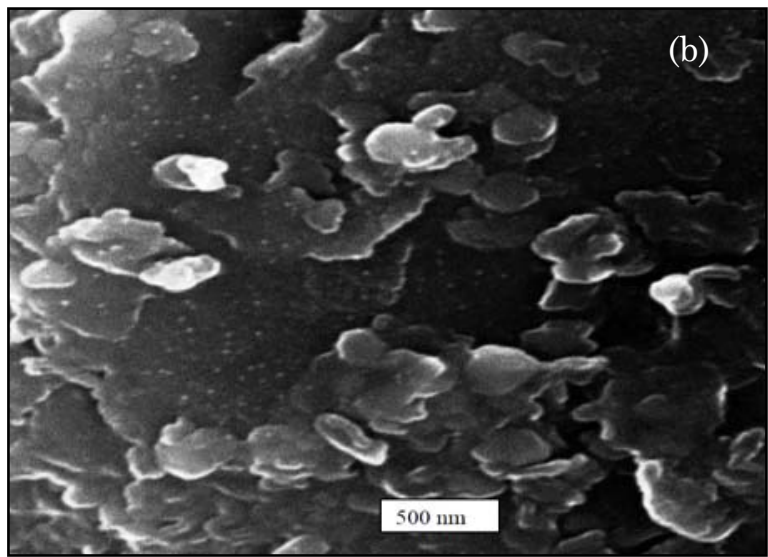

Figure 2. SEM image of Montmorilonite-KSF (a) and $\mathrm{Cu}$ (II)-Clay (b) 
We therefore examined the feasibility of reaction in other solvents, such as: acetonitrile, methanol, ethanol, DMF, and THF. The reaction was equally feasible ion other solvents as well, wherein use of acetonitrile, methanol, ethanol, and DMF gave the product in almost comparable yields, however, DMSO as a solvent significantly increased the reaction yields to $81 \%$ which may be attributed to the polar non-protic nature of DMSO. The reaction without the use of a solvent led to significant drops of product yields. We also investigated the reaction under sonication and microwave conditions. To our delight the reaction in microwave resulted in quantitative conversion to the products under solvent free condition in a matter of minutes. The identification of the optimum catalyst loading was another important aspect of the reaction strategy. Decreasing the amount of catalyst to even $3 \mathrm{mg}$ resulted in product formation in as much as $98 \%$ yields.

We were further intrigued to investigate the impact of other clay catalysts on the present reactions (Table 2). The catalysts such as Kaoline, Montmorillonite-KSF, Montmorillonite$\mathrm{K} 10$, and bentonite did not give any product formation. The Pd/Montmorillonite-KSF though gave corresponding product albeit in low yields. The other montmorillonite based catalysts viz., Ni/Montmorillonite-KSF, Co/Montmorillonite-KSF, Sn/Montmorillonite$\mathrm{KSF}$, and $\mathrm{Zn} /$ Montmorillonite-KSF gave the products in trace amounts. Furthermore, the use of $\mathrm{PdCl}_{2}$ and $\mathrm{CuO}$ as well did not offer any increased yield of product formation. The $\mathrm{Cu}$ (II) doped clay catalyst was found to show much better results than commercially available $\mathrm{CuO}$ for the model reaction under optimized conditions. This may be attributed to the high dispersion and the nano-sized character of $\mathrm{Cu}$ (II) ions on clay support [21].

After investigating the various reaction procedures, the best reaction conditions obtained was identified: $5 \mathrm{mg} \mathrm{Cu}$-Clay catalyst 2 bromobenzaldehyde $(1.0 \mathrm{mmol})$, aniline (1.2 mmol), sodium azide $(1.8 \mathrm{mmol})$, and catalyst

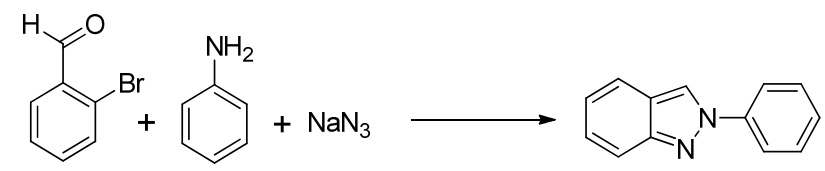

Scheme 2. Reaction in the presence of various catalysts

Table 1. Synthesis of $2 \mathrm{H}$-indazoles using $\mathrm{Cu}$-Clay catalyst under different reaction conditions (Scheme 1)

\begin{tabular}{cccccc}
\hline Entry & Condition & Solvent & Time & Catalyst $(\mathrm{mg})$ & Yielda $(\%)$ \\
\hline 1. & Stirring at room T & Toluene & $2 \mathrm{~h}$ & 15 & N.R. \\
2. & Stirring at $120^{\circ} \mathrm{C}$ & Toluene & $2 \mathrm{~h}$ & 15 & 34 \\
3. & Stirring at $120^{\circ} \mathrm{C}$ & Acetonitrile & $2 \mathrm{~h}$ & 15 & 59 \\
4. & Stirring at $120^{\circ} \mathrm{C}$ & Methanol & $2 \mathrm{~h}$ & 15 & 66 \\
5. & Stirring at $120^{\circ} \mathrm{C}$ & Ethanol & $2 \mathrm{~h}$ & 15 & 51 \\
6. & Stirring at $120^{\circ} \mathrm{C}$ & DMF & $2 \mathrm{~h}$ & 15 & 62 \\
7. & Stirring at $120^{\circ} \mathrm{C}$ & DMSO & $2 \mathrm{~h}$ & 15 & 81 \\
8. & Stirring at $120^{\circ} \mathrm{C}$ & THF & $2 \mathrm{~h}$ & 15 & 45 \\
9. & Stirring at $120^{\circ} \mathrm{C}$ & Solvent free & $2 \mathrm{~h}$ & 15 & 13 \\
10. & Microwave & Solvent free & $10 \mathrm{~min}$. & 15 & 98 \\
11. & Microwave & Solvent free & $8 \mathrm{~min}$. & 15 & 98 \\
12. & Microwave & Solvent free & $6 \mathrm{~min}$. & 15 & 73 \\
13. & Microwave & Solvent free & $8 \mathrm{~min}$. & 10 & 98 \\
14. & Microwave & Solvent free & $8 \mathrm{~min}$. & 5 & 98 \\
15. & Microwave & Solvent free & $8 \mathrm{~min}$. & 3 & 78 \\
16. & Microwave & Solvent free & $10 \mathrm{~min}$ & No catalyst & N. R. \\
\hline
\end{tabular}

$\mathrm{a}=$ isolated yield 
(5 mg) under microwave and solvent free conditions.

Using the optimized reaction conditions, the substrate scope of the condensation reaction was then examined for the synthesis of substituted $2 \mathrm{H}$-indazoles. Substituted anilines were well tolerated to reaction conditions. Substituted halogens were found to be the good substrates for heterocyclization. Electron donating groups, e.g. methoxy, as well as electro withdrawing groups, e.g. nitro and triflouromethoxy groups, have no significant effect on the reaction yields. Also, the halogen substitution a tortho position gave the product formation in excellent yields.

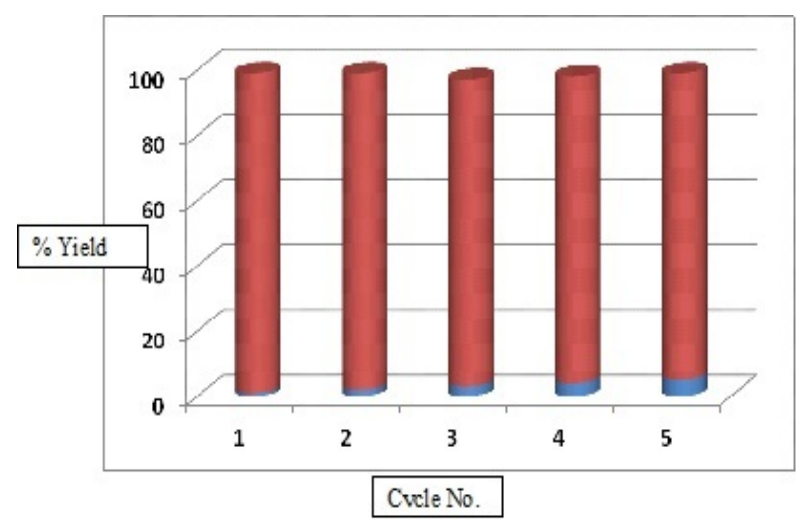

Figure 3. Recyclability of the catalyst for on pot synthesis of $2 \mathrm{H}$-indazole ${ }^{\mathrm{a}}(\mathrm{a}=$ model reaction, red bars indicate product yield and blue bars indicate decrease in yield
Recyclability of the catalyst was investigated using model reaction between bromobenzaldehyde $(1.0 \mathrm{mmol})$, aniline $(1.2 \mathrm{mmol})$, sodium azide $(1.8 \mathrm{mmol})$, and catalyst $(5 \mathrm{mg}) \mathrm{un}$ der microwave and solvent free conditions. This experiment proved excellent recycling capability of the catalyst without significant loss of activity and the catalyst could be easily recovered by simple filtration and reused, leading to corresponding $2 \mathrm{H}$-indazole in quantitative yield even up to five consecutive cycles (Figure 3).

On the basis of previous studies [26] a probable mechanism is shown in Scheme 3 . The multicomponent one-pot coupling reaction first engages the formation of the $\mathrm{N}-(2$ bromobenzylidene) amine intermediate. The bromide is substituted with azide in the presence of the $\mathrm{Cu}$ (II)-Clay catalyst in the next stage with the outcome of N-(2azidobenzylidene) amine. The azide in the intermediate thus formed, undergoes activation by the $\mathrm{Cu}$ (II)-Clay catalyst which leads to the desired $2 \mathrm{H}$-indazole product formation via intramolecular cyclization with N-N bond formation.

\section{Conclusions}

In conclusion, a microwave assisted and solvent-free synthesis of $2 \mathrm{H}$-indazoles using $\mathrm{Cu}$ (II)-Clay is an efficient heterogeneous catalyst. This protocol is novel, simple, and proficient for three component consecutive conden-

Table 2. Reaction in the presence of various catalysts (Scheme 2)

\begin{tabular}{clcc}
\hline Entry & Catalyst & Catalyst loading $(\mathrm{mg})$ & Yield $^{\mathrm{a}}(\%)$ \\
\hline 1. & Kaoline & 5 & $\mathrm{NR}$ \\
2. & Montmorillonite-KSF & 5 & $\mathrm{NR}$ \\
3. & Montmorillonite-K10 & 5 & $\mathrm{NR}$ \\
4. & Bentonite & 5 & $\mathrm{NR}$ \\
5. & $\mathrm{Pd} /$ Montmorillonite-KSF & 5 & 47 \\
6. & $\mathrm{Cu} /$ Montmorillonite-KSF & 5 & 98 \\
7. & Ni/Montmorillonite-KSF & 5 & 11 \\
8. & Co/Montmorillonite-KSF & 5 & 13 \\
9. & $\mathrm{Sn} /$ Montmorillonite-KSF & 5 & traces \\
10. & $\mathrm{Zn} /$ Montmorillonite-KSF & 5 & traces \\
11. & $\mathrm{PdCl} l_{2}$ & 5 & Traces \\
12. & $\mathrm{CuO}$ & 5 & 53 \\
13. & $\mathrm{No}$ Catalyst & $\cdots$ & NR \\
\hline
\end{tabular}

Reaction time $8 \mathrm{~min},{ }^{a}=$ isolated yield; NR: No Reaction 


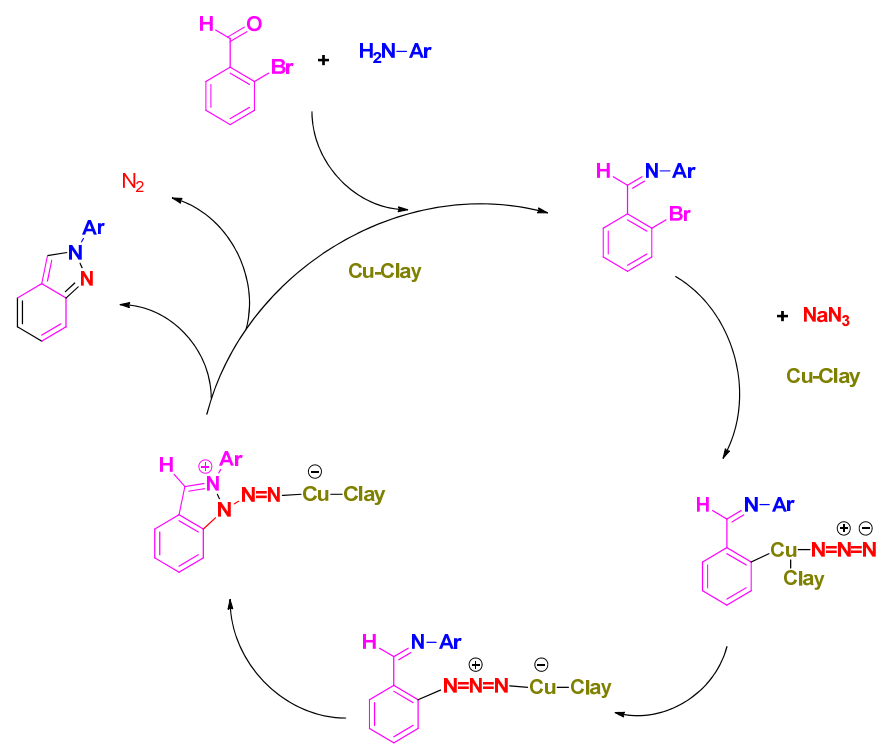

Scheme 3. A possible reaction mechanism for $\mathrm{Cu}$ (II)-Clay catalysed $2 \mathrm{H}$-indazoles formation

sation, $\mathrm{C}-\mathrm{N}$ and $\mathrm{N}-\mathrm{N}$ bond formations as a one-pot MCR. The catalyst was easy to prepare, environmentally friendly, highly stable, leaching-free, and can be recycled several times without significant loss of activity. Moreover, being fast and high yielding, this protocol will be highly useful for economical synthesis of $2 \mathrm{H}$ indazoles.

\section{References}

[1] Kharitonov, V.G., Sharma, V.S., Magde, D., Koesling, D. (1999). Kinetics and Equilibria of Soluble Guanylate Cyclase Ligation by CO: Effect of YC-1. Biochemistry, 38: 10699-10706.

[2] Morie, T., Harada, H., Kato, S. (1997). Convenient Synthesis of N-(2,2-dimethyl-1,3dioxan-5-yl)-1 H-indazole-3-carboxamide, the Intermediate of 5-HT3 Receptor Antagonist. Synthetic Communication. 27: 559-566.

[3] Fang, Y.L., Jin, C.L., Li, J.H., Tsang, M.H., Sheng, C.T., Che, M.T., Chin, C.W., Fong, C.C., Sheng, C.K. (2001). Synthesis of 1benzyl-3-(5'-hydroxymethyl-2'-furyl)indazole Analogues as Novel Antiplatelet Agents. Journal of Medicinal Chemistry, 44: 37463749 .

[4] Bonde, N., Gaikwad. (2004). Synthesis and Preliminary Evaluation of Some Pyrazine Containing Thiazolines and Thiazolidinones as Antimicrobial Agents. Bioorganic and Medicinal Chemistry, 12: 2151-2161.

[5] Haung, L.J., Shih, M.L., Chen, H.S., Pan, S.L., Teng, C.M., Lee, F.Y., Kuo, S.C. (2006). Synthesis of $\mathrm{N}_{2}$-(substituted benzyl)-3-(4methylphenyl)indazoles as Novel Anti- angiogenic Agents. Bioorganic and Medicinal Chemistry, 14: 528-536.

[6] Vijay, A.M., Antony, J.A., Chandrakumar, R.R., Koilraj, M., Sujatha, R., Shanmugsundram, P. (2008). Synthesis and Biological Activities of A Novel Series of Indazole Derivatives. Bioscience and Biotechnology Research, 5: 313-318.

[7] Ye, M., Edmunds, A.J., Morris, J.A., Sale, D., Zhang, Y., Yu, J.Q. (2013). A Robust Protocol for Pd(II)-catalyzed C-3 Arylation of $(1 \mathrm{H})$ Indazoles and Pyrazoles: Total Synthesis of Nigellidine Hydrobromide. Chemical Science, 4: 2374-2379

[8] Yadav, J.S., Reddy, B.V.S., Sadasive, K., Satheesh, G. (2002). 1,4-Conjugate Addition of Allyltrimethylsilane to a,B-unsaturated Ketones. Tetrahedron Letters, 43: 9695-9697.

[9] Kazzouli, S.E., Bouissane, L., Khouili, M., Guillaumet, G. (2005). Synthesis of 4Substituted and 3,4-Disubstituted Indazole Derivatives by Palladium-Mediated CrossCoupling Reactions. Tetrahedron Letters, 46: 6163-6167.

[10] Nathan, E.G., Liuqing, W., Gary, E.A. (2014). Regioselective Synthesis of $2 \mathrm{H}$-Indazoles Using a Mild, One-Pot Condensation-Cadogan Reductive Cyclization. Organic Letters, 16: 3114-3117.

[11] Yuesi, F., Chunrui, W., Richard, C., Larock, Fenf.S. (2011). Synthesis of 2H-Indazoles by the [3 + 2] Dipolar Cycloaddition of Sydnones with Arynes. Journal of Organic Chemistry, 76: 8840-8851.

[12] Goeminne, A., Scammells, P.J., Devine, S.M., Flynn, B.L. (2010). Richter cyclization and Co-cyclization Reactions of Triazene-masked Diazonium Ions. Tetrahedron Letters, 51: 6882-6885.

[13] Kim, K.Y., Shin, J.T., Lee, K.S., Cho, C.G. (2004). Cu(I) Mediated One-pot Synthesis of Azobenzenes from Bis-Boc Aryl Hydrazines and Aryl Halides. Tetrahedron Letters, 45:117-120.

[14] Kiyofumi, I., Mika, K., Takashi, Y., Yukari, A., Kou, H., Takao, S. (2007). Synthesis of 3substituted Indazoles and Benzoisoxazoles via Pd-catalyzed Cyclization Reactions: Application to the Synthesis of Nigellicine. Tetrahedron, 63: 2695-2711.

[15] Basuvaraj, S.K., Amarajothi, D., Kasi, P. (2014). K10 Montmorillonite Clays as Environmentally Benign Catalysts for Organic Reactions. Catalysis Science and Technology, 4: 2378-2396.

[16] Dar, B.A., Varsha, S., Amrita, B., Wagay, M.A., Baldev, S. (2015). An Expeditious N,Ndibenzylation of Anilines under Ultrasonic Ir- 
radiation Conditions Using Low Loading $\mathrm{Cu}(\mathrm{II})$-Clay Heterogeneous Catalyst. Tetrahedron Letters, 56: 136-141.

[17] Dar, B.A., Nalini, P., Snehil, S., Purshotum, K., Farooqui, M., Baldev, S. (2015) Solventfree, Scalable and Expeditious Synthesis of Benzanilides under Microwave Irradiation Using Clay Doped with Palladium Nanoparticles as A Recyclable and Efficient Catalyst. Green Chemistry Letters and Reviews, 8: 1-8.

[18] Dar, B.A., Sara, K., Wani, T.A., Mir, M.A., Farooqui, M. (2015). Ceria-based Mixed Oxide Supported CuO: An Efficient Heterogeneous Catalyst for Conversion of Cellulose to Sorbitol. Green and Sustainable Chemistry, 5: 1524.

[19] Dar, B.A., Dangroo, N.A., Amit, G., Aarti, W., Khuroo, M.A., Vishwakarma, R.A., Baldev, S. (2014). Iodine Catalyzed Solvent-free Crossdehydrogenative Coupling of Arylamines and H-Phosphonates for the Synthesis of NArylphosphoramidates under Atmospheric Conditions. Tetrahedron Letters, 55: 15441548.

[20] Dar, B.A., Amrita, B., Amit, S., Parduman, R.S., Anish, L., Singh, A.P., Meena, S., Baldev, S. (2013). Ultrasound Promoted Efficient and Green Protocol for the Expeditious Synthesis of 1,4 Disubstituted 1,2,3-triazoles Using $\mathrm{Cu}(\mathrm{II})$ Doped Clay as Catalyst. Applied Clay Science, 80-81: 351-357

[21] Dar, B.A., Prince, B., Singh, A.P., Anish, L., Parduman, R.S., Meena, S., Baldev, S. (2013). Clay Entrapped $\mathrm{Cu}(\mathrm{OH}) \mathrm{x}$ as An Efficient Heterogeneous Catalyst for Ipso-Hydroxylation of Arylboronic Acids. Applied Catalysis A: General, 466: 60-67.

[22] Mellouk, S., Cherifi, S., Sassi, M., MaroufKhelifa, K., Bengueddach, A., Schott, J., Khelifa, A. (2009). Intercalation of Halloysite from Djebel Debagh (Algeria) and Adsorption of Copper Ions. Applied Clay Science, 44: 230236.

[23] Deng, C., Hu, H., Ge, X., Han, C., Zhao, D., Shao, G. (2011). One-pot Sonochemical Fabrication of Hierarchical Hollow CuO Submicrospheres. Ultrasonics Sonochemistry, 18: 932937.

[24] Zhao, D., Zhou, J., Liu, N. (2006). Preparation and Characterization of Mingguang Palygorskite Supported with Silver and Copper for Antibacterial Behaviour. Applied Clay Science, 33: 161-170.

[25] Alvarez-Puebla, R.A., Aisa, C., Blasco, J.J., Echeverría, C., Mosquera, B., Garrido, J. (2004). Copper Heterogeneous Nucleation on A Palygorskitic Clay: an XRD, EXAFS and Molecular Modeling Study. Applied Clay Science, 25:103-110
[26] Yong, K., Manian, R.K., Namjin, P., Yumi, H., Sunwoo, L. (2011). Copper-Catalyzed, One-Pot, Three-Component Synthesis of Benzimidazoles by Condensation and $\mathrm{C}-\mathrm{N}$ Bond Formation. Journal of Organic Chemistry, 76: 9577-9583

\section{Appendices}

\section{Spectral data of some representative com- pounds}

2-Phenyl-2H-indazole: ${ }^{1} \mathrm{H}$ NMR $(400 \mathrm{MHz}$, $\left.\mathrm{CDCl}_{3}\right): \delta 8.45(\mathrm{~d}, J=1.2 \mathrm{~Hz}, 1 \mathrm{H}), 7.97-7.93(\mathrm{~m}$, $2 \mathrm{H}), 7.86-7.83(\mathrm{~m}, 1 \mathrm{H}), 7.77-7.74(\mathrm{~m}, 1 \mathrm{H}), 7.60-$ $7.54(\mathrm{~m}, 2 \mathrm{H}), 7.47-7.42(\mathrm{~m}, 1 \mathrm{H}), 7.40-7.34(\mathrm{~m}, J$ $=8.4,6.6,0.9 \mathrm{~Hz}, 1 \mathrm{H}), 7.16(\mathrm{~m}, J=8.4,6.6,0.9$ $\mathrm{Hz}, 1 \mathrm{H}) ; 13 \mathrm{C}$ NMR (100 MHz, CDCl3): $\delta$ 150.1, $140.8,129.9,128.2,127.1,123.0,122.7,121.3$, 120.7 (2C), 118.2; MS (EI) m/z: $195\left[\mathrm{M}^{+}+1\right]$.

2-p-Tolyl- $2 H$-indazole: ${ }^{1} \mathrm{H} \quad \mathrm{NMR} \quad(400 \mathrm{MHz}$, $\left.\mathrm{CDCl}_{3}\right): \delta 8.37(\mathrm{~d}, J=0.9 \mathrm{~Hz}, 1 \mathrm{H}), 7.81-7.75(\mathrm{~m}$, $3 \mathrm{H}), 7.70(\mathrm{~m}, 8.4,0.9 \mathrm{~Hz}, 1 \mathrm{H}), 7.34-7.29(\mathrm{~m}$, $3 \mathrm{H}), 7.13-7.08(\mathrm{~m}, J=8.7,6.6,0.9 \mathrm{~Hz}, 1 \mathrm{H}), 2.42$ (s, 3H); ${ }^{13} \mathrm{C} \mathrm{NMR}\left(100 \mathrm{MHz}, \mathrm{CDCl}_{3}\right): \delta 149.6$, 138.2, 137.9, 130.06, 126.6, 122.7, 122.3, 120.8 (2C), 120.3, 117.8, 21.0; MS (EI) $\mathrm{m} / z: 209\left[\mathrm{M}^{+}\right.$ +1 .

2-(4-chlorophenyl)- $2 H$-indazole: ${ }^{1} \mathrm{H}$ NMR (400 $\left.\mathrm{MHz}, \mathrm{CDCl}_{3}\right): \delta 8.35(\mathrm{~d}, J=0.9 \mathrm{~Hz}, 1 \mathrm{H}), 7.86-$ $7.71(\mathrm{~m}, 2 \mathrm{H}), 7.78-7.75(\mathrm{~m}, 1 \mathrm{H}), 7.68(\mathrm{~m}, J=$ 8.7, $0.9 \mathrm{~Hz}, 1 \mathrm{H}), 7.50-7.49(\mathrm{~m}, 2 \mathrm{H}), 7.32(\mathrm{~m}$, 8.7, 6.6, $1.2 \mathrm{~Hz}, 1 \mathrm{H}), 7.11(\mathrm{~m}, J=8.4,6.6$, $0.9 \mathrm{~Hz}, 1 \mathrm{H}) ;{ }^{13} \mathrm{C}$ NMR $\left(100 \mathrm{MHz}, \mathrm{CDCl}_{3}\right): \delta$ $149.8,138.9,133.5,129.6,127.1,122.8,122.7$, 121.9, 120.3, 120.2, 117.8; MS (EI) $m / z: 230\left[\mathrm{M}^{+}\right.$ +1 . 